\title{
XXXVI. Notes on the geographical distribution of organic remains contained in the oolitic series of the Great London and Paris Basin, and in the same series of the South of France
}

\section{Henry T. De la Beche F.R.S.}

To cite this article: Henry T. De la Beche F.R.S. (1830) XXXVI. Notes on the geographical distribution of organic remains contained in the oolitic series of the Great London and Paris Basin, and in the same series of the South of France, Philosophical Magazine Series 2, 7:40, 250-268, DOI: $10.1080 / 14786443008675283$

To link to this article: http://dx.doi.org/10.1080/14786443008675283

曲 Published online: 13 Jul 2009.

Submit your article to this journal $₫$

щll Article views: 3

Q View related articles ¿ 
produced by the rising of the aqueous vapours has ceased, throw in another portion, and so on; and keep the crucible, when the whole mixture has been introduced, for about one hour in a moderate red glowing heat (if the heat is too great, it destroys the colour); when cold, pour water into the crucible, and separate by means of it the brown residue of sulphur mixed with the ultramarine. A superabundance of sulphur may be expelled by a moderate heating. If the colouring is not of an equal intensity, the most fiery ultramarine (and this is a very important circumstance) may be obtained by washing, and separating it from those parts which are less coloured. From the component parts of the ultramarine as given by the analysis, it cannot be formed, without a medium. Thus this colour is nothing else than a silicate of soda dyed with sulphuret of sodium.

! The natural ultramarine contains a not inconsiderable portion of potash and sulphuric acid; and it is very probable that the artificial production here mentioned may be usefully varied, but this can only be discovered by experiment."

XXXVI. Notes on the Geographical Distribution of Organic Remains contained in the Oolitic Series of the Great London and Paris Basin, and in the same Series of the South of France. By Henry T. De la Beche, F.R.S. \& c.

[Continued from page 205.]

Lowest System.-Subdivisions: Cornbrasi, Forest Marble, and Great Oolite.

I $T$ has been considered that the former of these is a proper subdivision, and may be traced to considerable distances, but that the two latter may pass into or represent each other. Great difficulty must always attend these minute divisions. Mr. Phillips gives only five feet as the thickness of the cornbrash in Yorkshire; it is represented as from eight to sixteen feet in the neighbourhood of Tellisford and Farley Castle, near Bath; M. de Caumont doubts its existence in Calvados, though there is a rock which $M$. Desnoyers and myself consider may be referred to it; and $M$. Boblaye mentions it in the North of France, but it does not so clearly appear to exist in the South of the same country. The forest marble and great oolite seem to occur extensively. In Calvados the latter, according to M. de Caumont, is intimately connected with the inferior oolite.

Mr. Phillips observes (Illustrations, \&c. p. 158), "In the midland counties, the fuller's earth rock of Mr. Smith does by 
no means furnish a constant or well-marked line of distinction between the middle, great, or Bath oolite, and the inferior oolite; and I am decidedly of opinion that in the northern part of Northamptonshire, and throughout Rutland and Lincolnshire, there is but one thick oolite rock beneath the cornbrash, resting upon brown sandstone which immediately covers the upper lias shale."

\section{Great Oolite and Forest Marble.}

In Yorkshire, above and beneath the rocks considered by Mr. Phillips equivalent to the Bath oolite, there are two large deposits of coal, sandstone and shale, containing many fossil plants. In the inferior the following genera are found: Equisetum, 2 species.-Lycopodites, 1.-Thuytes, 1.-Scolopendrium, 1.-Sphænopteris, 4.-Neuropteris, 1.-Pecopteris, 2. -Cycadites, 4.-Flabellaria? 1. In the superior: Equisetum, 1.-Lycopodites, 1.-Thuytes, 1.-Scolopendrium, 1.Aspleniopteris, 1. -Sphænopteris, 4.-Neuropteris, 1.-Pecopteris, 8.- Cycadites, 4.-Flabellaria? 1.-Phyllites, 1.and Dicotyledonous Wood.

\section{Organic Remains of the Great Oolite,-Yorkshire.*}

Plesiosaurus?

Plants.

Millepora straminea (Phil.).

Retepora?

Tubipora or Eunomia.

Cidaris vagans.

Echinus germinans.

Mya calceiformis (Phil.).

Panopa gibbosa?

Psammobia lævigata (Phil.).

Amphidesma decurtatum.

Pholadomya acuticostata.

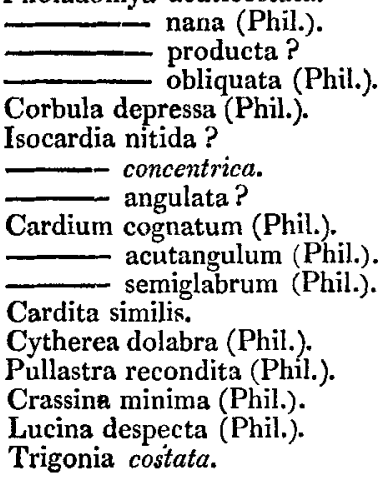

Trigonia conjungens.

Modiola imbricata.

ungulata (Y.\& B.).

Pinna cuneata (Phil.).

Cucullæa imperialis (Bean.).

_ cylindrica (Phil.).

- cancellata (Phil.).

Nungata.

Nucula variabilis.

Perna lacryma.

Perna quadrata.

Gervillia acuta.

Avicula Braamburiensis.

Plagiostoma cardiiforme.

Pecten lens.

- demissus (Phil.).

- abjectus (Phil.).

Lima rudis.

Ostrea Marshii.

- gregarea? sulcifera (Phil.).

Gryphæa bullata? or gigantea.

Terebratula spinosa (Smith). globata.
intermedia.

Natica adducta (Phil.).

Turbo muricatus?

* Illustrations of the Geology of Yorkshire, p. 149-152. 


\section{$252 \mathrm{Mr}$. De la Beche on the Geographical Distribution of Organic}

Trochus monilitectus (Phil.).

Delphinula?

Phasianella cincta (Phil.).

Turritella eingenda.

Melania Heddingtonensis.

Mtriata?

Terebra vetusta (Phil.).
Actæon glaber (Bean.).

Rostellaria composita?

Nautilus.

Belemnites abbreviatus (Miller).

Ammonites Blagdeni.

Vermicularia nodus (Phil.).

Serpula lacerata (Phil.).

\section{Organic Remains of the Forest Marble.-Calvados.*}

Terebellaria ramosissima

Berenicea diluviana

Alecto dichotoma

Idmonea triquetra

Theonoa chlatratra

Chrysaora damecornis

- spincsa

Eunomia radiata

Spiropora tetragona

cespitosa
elegans
intricata

Fungia orbulites

Millepora dumetosa

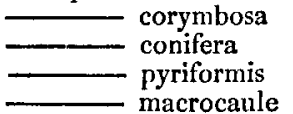

Caryophyllia truncata

- Brebissonii

Limnorea mamillaris

Entalophora cellarioides

Turbinolopsis ochracea

Eschara.

Alcyonium.

Clypeus sinuatus.

clunicularis.

Encrinites pyriformis.

Pentacrinites.

Apiocrinites.

Asteria.

Crustacea.

Modiola elegans.

Trigonia costata.
Trigonia gibbosa.

Avicula duplicata.

- costata.

Gervillia pernoïdes (Deslong.).

-_- siliqua.

monotis (Desl.).

-.- costellata (Desl.).

Lima proboscidea.

Plagiostoma punctatum.

Pecten corneus.

- vimineus.

Ostrea Marshii.

palmetta.

Pinna pinnigena.

Mactra gibbosa.

Terebratula tetraëdra.

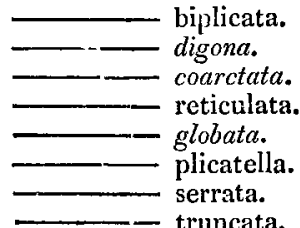

Patella rugosa.

Trochus elongatus.

Belemnites.

Nautilus truncatus.

Ammonites annulatus.

Nerinea.

Isocardia.

Lucina.

Plants.

\section{Organic Remains of the Great Oolite,-Calvados.}

Crocodile.

Megalosaurus.

Teeth and palates of Fish.

Ichthyodorulites (Buckl.\&De la B.).

Ammonites.

Belemnites.

Pinna.

Mytilus amplus.
Avicula inæquivalvis.

Lima gibbosa.

Ostrea Crista Galli.

Pecten corneus.

Terebratula biplicata.

Plants.

* De Caumont, Essai \&c. pp. 147, 148. 
Remains in the Oolite Series of England and France. 253

Organic Remains of the Fuller's Earth (Terre à Foulon),-

Ammonites. North of France.*

Nautilus.

Belemnites compressus.

Terebratula media.

Lutraria? Donacites? Casts.

Terebratula approaching vulgaris.

Donacites Alduini?

Organic Remains of the Great Oolite,-North of France.

M. Boblaye states $\dagger$ that the fossils which appeared to him the most proper to characterize, by their abundance, the lowest beds, are Ostrea acuminata, Terebratula media, and a Madrepore composed of small cylindrical tubes united in bundles.

Organic Remains of the White Marls (Bradford Clay) in the North of France. $\neq$

Ammonites vulgaris.

Nerinea.

Turritella.

Ampullaria or Turbo?

Serpula.

Pecten.

Spondylus imbricatus (or Podopsis).

Pinna (species analogous to that of the Ile d'Aix).

Avicula echinata.

Ostrea costata.

- acuminata.

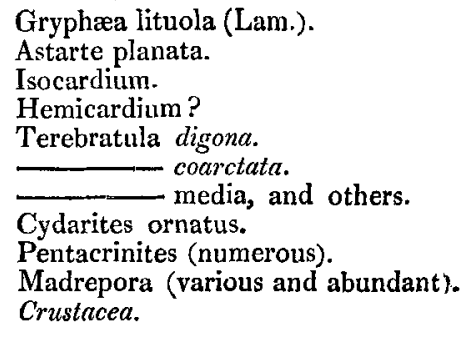

The most characteristic fossils are considered to be Gryphæa lituola, Terebratula digona, and T. coarctata.

\section{Connbrash.}

Organic Remains of the Cornbrash in Yorkshire. $\$$

Cellaria Smithii.

Millepora straminea (Phil.).

Cidaris vagans.

Clypeus clunicularis.

orbicularis.

Galerites depressus.

Pentacrinus Caput Medusæ.

Mya literata.

Sanguinolaria undulata.

Pholadomya Murchisoni.

Anoladonya

Amphidesma decurtatum (Phil.).

Unio peregrinus.

Isocardia minima.

Cardium citrinoïdeum (Phil.).

Trigonia clavellata.

Modiola cuneata.
Pinna cuneata (Bean.).

Plagiostoma rigidulum (Phil.).

Pecten fibrosus. demissus (Phil.).

Ostrea Marshii.

Terebratula ovoides.

Trochus granulatus.

Terebra? granulata (Phil.).

Melania Heddingtonensis.

Bittata (Phil.).

Bulla? or Actæon.

Ammonites Herveyi.

- terebratus.

Vermicularia nodus (Phil.).

Serpula intestinalis (Phil.).

Belemnites are not found in the cornbrash of Yorkshire.

* Boblaye, Ann.des Sci. Nat. vol. xvii. p. 57. † Ibid. pp. 58, 59.

$\$$ Ibid. pp. 60, 61: $\quad \oint$ Phillips's Illustrations, \&c. p. 143-145. 


\title{
254 Mr. Dela Beche on the GeographicalDistribution ofOrganic
}

\author{
Organic Remains of the Cornbrash and Forest Marble,-North \\ of France.* \\ Avicula echinata. \\ Plagiostoma cardiiforme. \\ Pecten fibrosus. \\ lens, and two others. \\ Gryphæa lituola. \\ Terebratula subrotunda. \\ Spatangus. \\ Nucleolites columbaria. \\ Millepora. \\ Fish teeth.
}

Ostrea, large and flat, hinge very broad.

It will at once be observed how very little the lists of organic remains enumerated at the different localities agree with each other. Unfortunately we have no good detailed and published lists of fossils in the rocks under consideration, either in our midland or southern counties; but as Mr. Conybeare's lists $\dagger$ are principally compiled from these parts of England, I shall employ them, though by their general nature they do not exactly enter into the object of these notes, adding those fossils that have appeared in Sowerby's Min. Conch. since the publication of the "Outlines."

The additions to Mr.Conybeare's lists are, for the cornbrash, Mytilus sublævis, Isocardia concentrica, Pecten annulatus, and Perna quadrata; - for the Stonesfield slate, Patella lata;-and for the Bradford clay, Terebratula coarctata, and Serpula triangulata. The additions to the list of great oolite fossils are considerable; the following are all from Ancliff in the environs of Bath.

\section{Fossils of the Great Oolite,-Ancliff.}

Astarte orbicularis.

Aumila.

Cucullæa minuta.

Pectunculus minimus.

- oblongus.

Arca pulchra.

Nucula variabilis.

- mucronata.

Ostrea obscura.

- costata.

Gryphaea minuta.

Trigonia imbricata.

_- cuspidata.

- Pullus.

Terebratula flabellula.
Terebratula furcata.

Orbicula granulata.

Patella ancyloides.

- - nana.

Emarginula scalaris.

Actæon cuspidatus.

- acutus.

Nerita minuta.

- costata.

Turbo obtusus.

Rissoa lavis.

--- acuta.

--. obliquata.

--- duplicata.

Buccinum unilineatum.

* Boblaye, Ann. des Sci. Nat. vol. xvii. pp. 62,63.

+ Outlines of the Geology of England and Wales, p. 206-212. 


\section{Comparative View of the Organic Remains of the Great Oolite (including Fuller's Earth and Bradford Clay), the Forest Marble, and the Cornbrash.}

\section{F. E. Fuller's Earth.-G. O. Great Oolite--B. C. Bradford Clay.-}

F. M. Forest Marble.-C. Cornbrash.

\begin{tabular}{|c|c|c|c|c|}
\hline Name. & $\begin{array}{c}\text { England. } \\
\text { Conyb. and Sow. }\end{array}$ & $\begin{array}{c}\text { Yorkshire. } \\
\text { Phillips. }\end{array}$ & $\begin{array}{c}\text { Calvados. } \\
\text { De Caumont. }\end{array}$ & $\begin{array}{c}\text { North of France. } \\
\text { Boblaye. }\end{array}$ \\
\hline 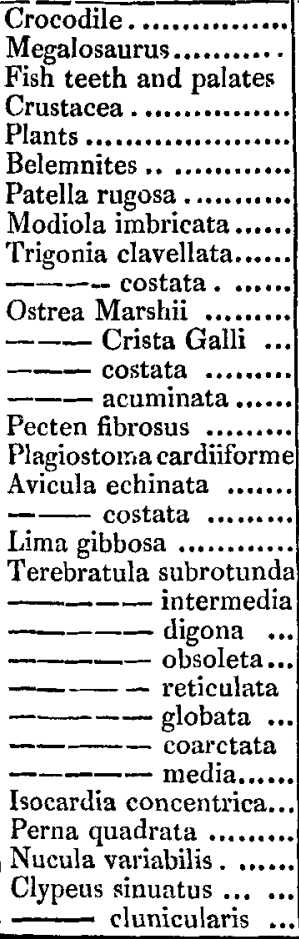 & 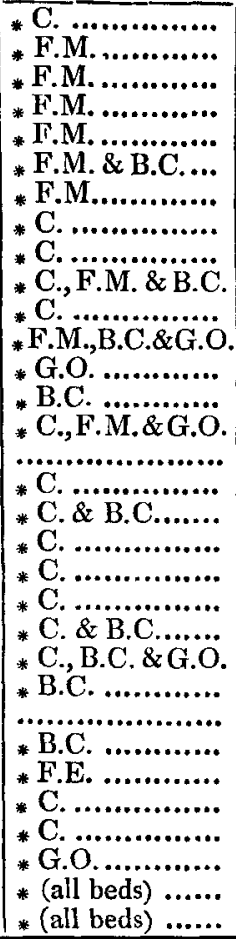 & 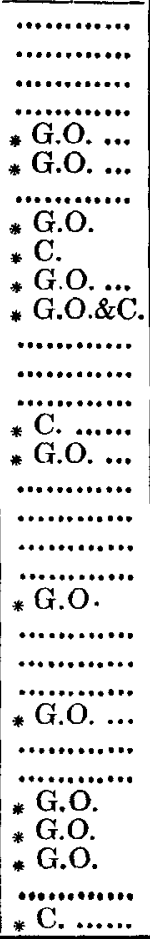 & 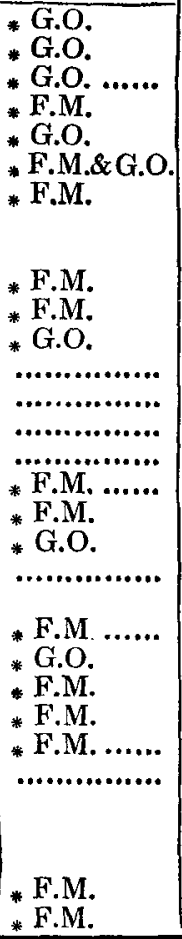 & $\begin{array}{l}\text { * B.C. } \\
* \text { G.O. \& B.C. } \\
* \text { F.M. \& C. } \\
* \text { C. \& F.M. } \\
\text { * B.C., \&.\&F.M. } \\
\text { * C.\& F.M. } \\
\text { * B.C. }\end{array}$ \\
\hline
\end{tabular}

There are abundant remains of corals or polypifers in the great oolite or in the forest marble in the South of England, Normandy, and North of France.

From the above comparative list it will be perceived that there is a more general agreement between Mr. Conybeare's lists (obtained from the midland and southern counties of England) and those of Normandy, than there is between the same lists and those formed in Yorkshire;-possibly the circumstances that produced the coal and abundance of plants 


\section{$256 \mathrm{Mr}$. Dela Beche on the Geographical Distribution of Organic}

which accompany it in the latter locality, may have had great influence on the animal life of the vicinity.

M. Dufrénoy mentions that in the oolite beds of Mauriac, the upper contain many polypifers, and appeared to him analogous with the calcaire à polypiers of Caen (cornbrash and forest marble). He enumerates the following fossils in these beds :

Pecten obscurus.

Pibrosus.

Terebratula subrotunda.

perovalis.

- - - concinna.

Plagiostoma punctatum? ovale.
Modiola cuneata?
Unio crassissimus.
Melania striata?
Ammonites annulatus.
Patella.
Echinites (very small).
Encrinites.
Madrepores.

At Maisons Blanches, Ruffec, and Négres near Couhé, M. Dufrénoy remarks, "In the first of these localities the rock contains an abundance of smooth Terebratula ; and strikingly resembles the limestone observed between Oxford and Blenheim, referred to the cornbrash." The fossils are:

Pecten obscurus.

laminatus.

barbatus.

Plagiostoma punctatum.

Terebratula perovalis.

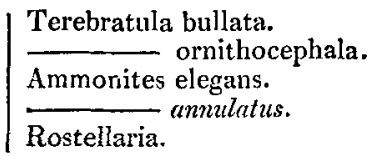

Of the 26 species mentioned in the Yorkshire cornbrash, 3 occur in France, one (Ostrea Marshii) being the same with one of the 3 of the great oolite: of these, 1 is found in the forest marble of Calvados; 1 in the forest marble and cornbrash of the North of France; and 2 in the Mauriac beds, South of France. Of the two Echinites of the Yorkshire cornbrash, $l$ is found in the forest marble of Calvados.

Of the 32 species of fossil shells enumerated in the forest marble of Calvados, 7 are found in the other localities : of these, 3 occur in the great oolite, and 1 in the cornbrash of Yorkshire; 3 in the white marls or Bradford clay of the North of France; and 1 in the Mauriac beds, South of France. Of these 32 species, 7 are noticed in the lists of Mr. Conybeare and Mr. Sowerby; 2 in the forest marble, 5 in the cornbrash, and 5 in the Bradford clay.

Of the 6 species noticed in the forest marble and cornbrash of the North of France, 3 are found in the lists of $\mathrm{Mr}$. Conybeare and Mr. Sowerby: of these, 3 occur in the cornbrash, 1 in the forest marble, and 1 in the great oolite. Of the same 3 species, 1 occurs in the great oolite, and 1 in the cornbrash of Yorkshire; 1 in the forest marble of Calvados; and 2 in the Mauriac beds, South of France. 
Of the 61 species of fossil shells enumerated in the Yorkshire great oolite, 7 occur in the lists of Mr. Conybeare and Mr. Sowerby : and of these, 6 are mentioned in the cornbrash, 1 in the forest marble, 1 in the Bradford clay, and 1 in the great oolite. Of the 61 species, 3 are stated to occur in the forest marble of Calvados, and 1 is found in the cornbrash and forest marble of the North of France. Melania striata is marked questionable in the great oolite of Yorkshire and in the Mauriac beds.

Of the 7 species noticed in the great oolite of Calvados, 3 occur in Mr. Conybeare's lists, 2 in the cornbrash, 1 in the forest marble, 2 in the Bradford clay, and 2 in the great oolite. None are mentioned either in Yorkshire or the North of France.

Of the 9 species contained in the white marls of the North of France, supposed equivalent to the Bradford clay, 4 occur in the lists of Mr. Conybeare and Mr. Sowerby, 2 in the cornbrash, and 3 in the Bradford clay. Of the 9 species, 3 are found in the forest marble of Calvados. None are mentioned in Yorkshire.

Of the 2 species noticed as characterizing the great oolite of the North of France, 1, Ostrea acuminata, is mentioned as found in the Bradford clay of Mr. Conybeare's lists, but is not noticed either in Calvados or Yorkshire.

Of the 3 species of shells, exclusive of Belemnites, in the fuller's earth of the North of France, 1, Terebratula media, is found in the same rock in England (Conybeare).

Of the 12 species enumerated in the Mauriac beds, 5 are found in the other localities, 2 being questionable: of these, 2 occur in the Yorkshire cornbrash, 1 being questionable at Mauriac; 1 is marked doubtful both in the Yorkshire great oolite and the Mauriac beds ; 2 occur in the cornbrash and forest marble of the North of France, and 1 in the forest marble of Calvados. Of these 12 species, 2 are found in $\mathrm{Mr}$. Conybeare's lists ; 1 in the cormbrash; and 1 in the cornbrash, forest marble, and Bradford clay.

By considering the cornbrash, forest marble, Bradford clay, great oolite, and fuller's earth, as a mass in which sometimes divisions can be made, while at others none can be observed, the most common fossils would appear to be fish teeth and palates, Clypeus clunicularis, Belemnites, Pecten fibrosus, Avicula echinata, Terebratula subrotunda, T. digona, $T$. coarctata, numerous polypifers, and the Bradford encrinite.

The following is a list of the fossils from the celebrated Stonesfield slate, which belongs to the division under consideN. S. Vol. 7. No. 40. April 1830.

$2 \mathrm{~L}$

ration, 
$258 \mathrm{Mr}$. De laBeche on the Geographical Distribution of Organic ration, formed from the writings of Professor Buckland*, Dr. Fitton $†$, and M. Adolphe Brongniart $\ddagger$.

Didelphis.

Pterodactylus.

Megalosaurus Bucklandi.

Tortoise scales.

Crocodile scales, teeth, and bones.

Fish teeth and palates.

Ichthyodorulites.

Insects.

Vegetable Remains.

Fucoides furcatus.

Sphenopteris hymenophylloides.

? macrophylla.

Tæniopteris latifolia.

Zamia pectinata.

- patens.

Thuytes divaricata.

- expansa.

_- acutifolia.

Taxitessiformis.

Taxites podocarpoides.

Shelis.

Nerita. 2 species ; one banded;

another banded and ribbed; both preserving their colour.

Turritella?

Another spiral univalve.

Astarte.

Avicula ovata.

Gryphæa. 2 species; one of small size, another large.

Lima rudis.

Mediola imbricato.

—_ aliformis.

$\overrightarrow{M y}$, another species.

Ostrea; a plicated species, and probably another.

Pecten fibrosus.

obscurrus.

Pholadomya acuticostata.

Pinna.

Plagiostoma; nearest to cardiiforme.

Terebratula obsoleta.

Trigonia impressa.

Of the 10 known species of fossil shells here enumerated, 3 are found in the Yorkshire great oolite, and 1 in the cornbrash of the same county; 1 occurs in the great oolite of Calvados; 1 in the cornbrash and forest marble of the North of France; and 2 in the Mauriac beds, South of France. The Plagiostoma cardiiforme, which one of the above shells is stated to approach, is found in the great oolite of Yorkshire, and in the cornbrash and forest marble of the North of France.

M. Dufrénoy presents us with the following list of organic remains found in the beds between the Pointe Duche, and the Pointe d'Angoulin. M. Dufrénoy seems inclined to refer the beds to the middle oolitic system; but their organic contents will do equally well, if not better, for that now under consideration.

Isocardia concentrica (Sow.).

Cardita obtusa (Sow.).

Terebratula triquetra (Sow.).

- ornithocephala.

Lima antiat (Sow.)

Lima antiqua (Sow.).

Actæon cuspidatus (Sow.).

Encrinites pyriformis.
Isocardia transversa (d'Obigny.). brevis (d'Obigny.).

Plagiostoma læviusculum (Sow.).

Lima rudis (Sow.).

Ostrea gregaria (Sow.).

- expansa ?? (Sow.).

Mya gibbosa (Sow.).

Modiola.

- Geological Transactions, New Series, vol. i. p. 394.

$\uparrow$ Zoological Journal, vol. iij. p. $41 \%$.

¥ See list of vegetable remains, inserted in the Tableau des Terrains qui composent l'écorce du Globe, par Alex. Brongniart, p. 413. 


\section{Remains in the Oolite Series of England and France. 259}

Nerinea. 2 species.

Gervillia.

Nerita.

Pteroceras.

Cidlarites.
Spines of Cidarites.

Polypifers. Many species.

Serpula.

Gryphæa? dilatata? ?

The same author presents us with the following list of organic remains from beds in the vicinity of La Rochelle, which may probably also belong to the system under consideration.

Astarte elegans (Sow.).

A pumila (Sow.).

Arca pulchra (Sow.).

Cucullaa elongata (Sow.).

Terebratula perovalis.

Modiola.

Lutraria ovalis (Sow.).

Lucina.

Pholadomya Proteii.

Middle Oolitic System.--Subdivision: Oxfond Cray and Kelloway Rock.

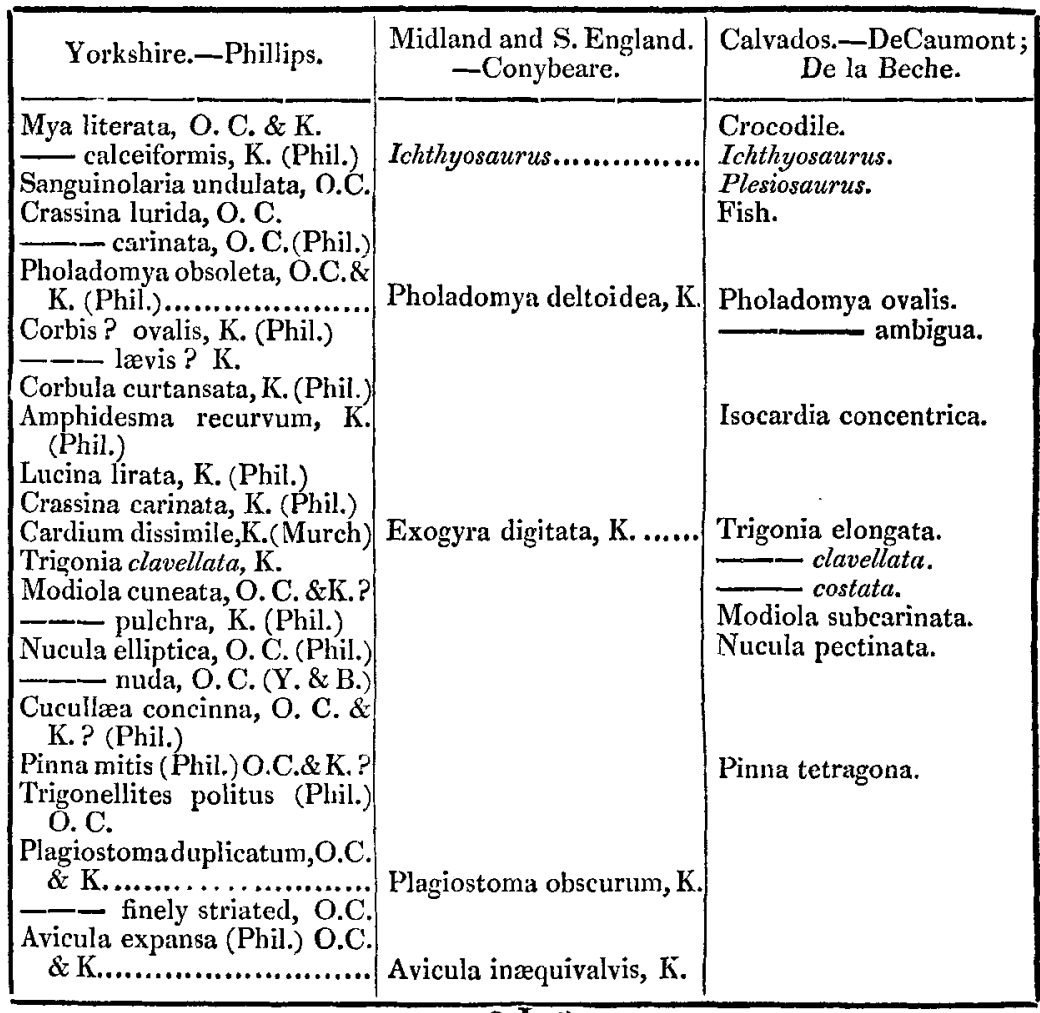

Mytilus pectinatus.

Turritella muricata.

Trigonia.

Dicerata.

Cardium.

Ammonites Lamberti.
Caryophyllia. 


\begin{tabular}{|c|c|c|}
\hline Yorkshire.-Phillips. & $\begin{array}{r}\text { Midland } \\
-\mathrm{Co}\end{array}$ & $\begin{array}{r}\text { Calvados }- \text { D } \\
\text { De la B }\end{array}$ \\
\hline 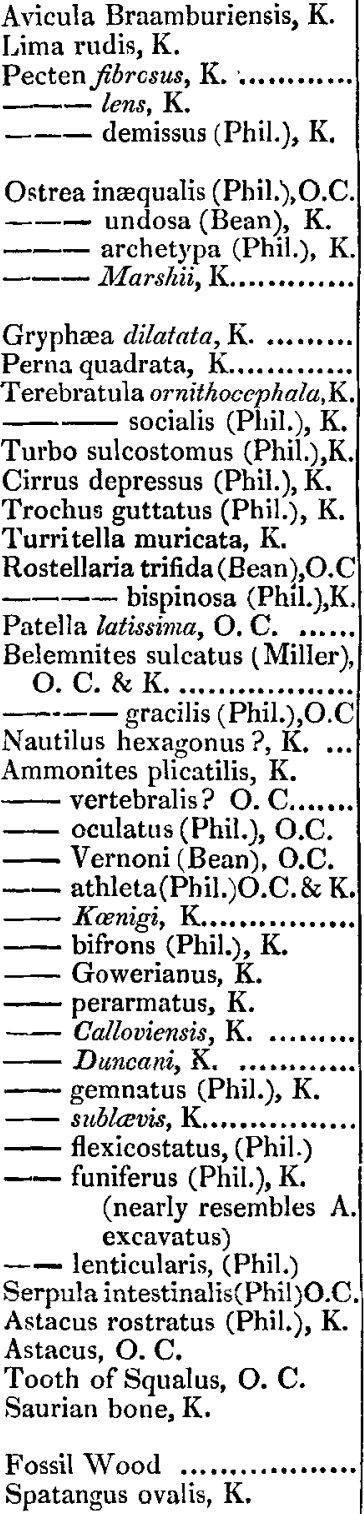 & $\begin{array}{l}\text { Rostellaria, O. C. \& K... } \\
\text { Patella latissima, O. C. } \\
\text { Belemnites, O. C. \& K.... } \\
\text { Nautilus, O. C. \& K. ...... } \\
\text { Ammonites armatus, O.C. }\end{array}$ & $\begin{array}{l}\text { plicomphalus. } \\
\text { acutus. } \\
\text { Duncani. } \\
\text { sublavis. } \\
\text { excavatus. } \\
\text { annulatus. } \\
\text { *Serpulat quadrangularis. } \\
\text { *Ananchites bicordata. } \\
\text { *Galerites depressa. } \\
\text { * patella. } \\
\text { * Nucleolites scutata. } \\
\text { Veget. remains(abundant.; }\end{array}$ \\
\hline
\end{tabular}

$\uparrow$ The organic remains marked with an asterisk are from the observations of M. Desnoyers. 
Remains in the Oolite Series of England and France. 261

M. Boblaye furnishes us with the following lists of organic remains in the Stenay blue marls and the Oxford clay; these he has kept distinct, because he is not certain whether the former should be united to the cornbrash or to the Oxford clay.

Fossils of the Stenay Blue Marls,-North of France.

Plesiosaurus.

Ammonites coronatus?

Serpula.

Ostrea nana? or Gryphæa.

Ostrea.

Trigonia costata.

clavellata.

Pecten (small).

Nucleolites.

Organic Remains, Oxford Clay,-North of France.

Ammonites.

Belemnites.

Ostrea pectinata.

- pennaria.

- gregarea.

— flabelloides (Lam.).

- deltoidea (Sow.).

Gryphæa dilatata.

Anomia.

Pinna lanceolata (Sow.).

Pholadomya.

Modiola tulipea (Laching P. Protei).

Mytilus.

Terebratula (approaching T. subrotunda).

Pecten.

From the above materials, the following list may be constructed, of organic remains which occur in more than one of the localities mentioned: the Stenay marls being considered as part of the Oxford clay; they may indeed represent the Kelloway rock.

\begin{tabular}{|c|c|c|c|c|}
\hline Name. & $\begin{array}{l}\text { York- } \\
\text { shire. }\end{array}$ & $\begin{array}{l}\text { Mid. and } \\
\text { S. Engl. }\end{array}$ & Calvados. & $\begin{array}{l}\text { North of } \\
\text { France. }\end{array}$ \\
\hline Plesiosaurus .............. & -. & .. & * & * \\
\hline Ichthyosaurus $\ldots \ldots \ldots \ldots \ldots$ & $\ddot{*}$ & * & * & . \\
\hline Trigonia clavellata $\ldots \ldots \ldots \ldots$ & *. & $\because$ & $*$ & $*$ \\
\hline 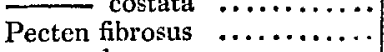 & $\ddot{*}$ & $\because$ & *. & . \\
\hline$\longrightarrow$ lens $\ldots \ldots \ldots \ldots \ldots$ & * & $\because$ & $*$ & $\cdots$ \\
\hline $\begin{array}{c}\text { Ostrea palmetta } \ldots \ldots \ldots \ldots \ldots \\
\text { Marshii } \ldots \ldots \ldots \ldots \ldots\end{array}$ & $\ddot{*}$ & .. & & $\ddot{*}$ \\
\hline$\longrightarrow$ gregarea...$\ldots \ldots \ldots$ & $\cdots$ & $\cdots$ & $*$ & * \\
\hline Gryphæa dilatata $\ldots \ldots \ldots$. & * & * & * & * \\
\hline Perna aviculoides..$\ldots \ldots \ldots$ & $\cdots$ & * & * & .. \\
\hline Terebratula ornithocephala .. & * & * & * & $\cdots$ \\
\hline Patella latissima $\ldots \ldots \ldots \ldots \ldots$ & " & * & $\because$ & 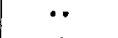 \\
\hline $\begin{array}{l}\text { Belemnites } \ldots \ldots \ldots \ldots \ldots \ldots \\
\text { Ammonites armatus } \quad \ldots \ldots \ldots\end{array}$ & * & * & 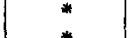 & * \\
\hline $\begin{array}{c}\text { Ammonites armatus } \ldots \ldots \ldots \\
\text { Kœnigi } \quad \ldots \ldots \ldots\end{array}$ & $\ddot{*}$ & * & .. & $\ddot{*}$ \\
\hline — Calloviensis ...... & - & $*$ & $\cdots$ & $\cdots$ \\
\hline$\longrightarrow$ Duncani.............. & * & * & * & $\because$ \\
\hline Vegetable Remains .......... & * & $*$ & $*$ & . \\
\hline
\end{tabular}


$262 \mathrm{Mr}$. De la Beche on the Geographical Distribution of Organic

Of the 63 species of fossils enumerated in the Oxford clay of Yorkshire, more than one half are new : but of the remainder, 12 occur in the other localities; of these, 8 are mentioned in Mr. Conybeare's lists, 7 are discovered in Normandy, and 2 in the North of France.

Of the 16 species noticed in Mr. Conybeare's lists of Midland and Southern England, 11 are found in the other localities, and of these, 8 occur in Yorkshire, 7 in Calvados, and 1 in the North of France.

Of the 34 species enumerated in Calvados, 12 are found in the other localities; and of these, 7 are discovered in Yorkshire, 7 in Midland and Southern England, and 4 in the North of France.

Of the 11 species, not questionable, mentioned as found in the North of France, 4 are discovered in the other localities; and of these, 2 occur in Yorkshire.

It will be observed that the Gryphra dilatata is found in all the localities; and that Ammonites Duncani, A. sublævis, and Terebratula ornithocephala, are common to England and Normandy.
Subdivision : Conal Rag, Oxford Oolite, and Calca- REOUs Grit.

Organic Remains of the lower Calcareous Grit of Yorkshire.*

Dicotyledonous Wood.

Spongia.

Crinoidal columns.

Echinus germinans.

Cidaris vagans.

Spatangus ovalis.

Clypeaster pentagonalis (Phil.).

Galerites depressus.

Pholadomya simplex (Phil.).

- deltoidea?

Sanguinolaria undulata.

Mya literata.

Isocardia tumida (Phil.).

Crassina carinata?

Venus.

Lucina crassa.

Modiola bipartita.

Avicula ovalis (Phil.).

Lima rudis.

\author{
Gryphæa bullata? \\ chamæformis. \\ inhærens. \\ Ostrea gregarea. \\ Terebratula socialis. \\ Cirrus cingulatus (Phil.). \\ Actæon retusus (Phil.). \\ Turritella muricata. \\ Rostellaria bispinosa? (Phil.). \\ Trochus granulatus. \\ - bicarinatus.
}

Belemnites sulcatus.

Ammonites Sutherlandiæ?

-__ perarmatus.

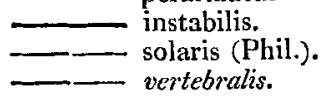

Dentalium.

Serpula Iacerata (Phil.).

Organic Remains of the Coralline Oolite of Yorkshire. $\uparrow$

Dicotyledonons Wood.

Crocodile.

Ichthyosaurus.

Palatal teeth of Fish.

Astacus rostratus (Phil.).

Spongia floriceps (Phil.).

'Turbinolia dispar (Phil.).

Caryophyllia cylindrica (Phil.).

* Phillips's Geology of Yorkshire, p. 134-136. † Ibid. p. 126-132. 
Remains in the Oolite Series of England and France. 263

Caryophyllia, like C. flexuosa (Sol. \& El.).

Astræa favosiödes (Smith). like C. cespitosa(S.\&EI.)

- inæqualis.

- micastron.

- arachnoides.

Meaudrina. tubulifera (Phil.).

Pentacrinus Caput Medusæ.

Cidaris forigemma (Phil.). intermedia (Flem.). monilipora (Y.\& B.).

Echinus germinans (Phil.).

Clypeus sinuatus.

Cmarginatus (Phil.).

- clunicularis.

- dimidiatus (Phil.).

- semisulcatus (Phil.).

Spatangus ovalis (Park.).

Galerites depressus.

Pholas recondita (Phil.).

Modiola? inclusa (Phil.).

Mya literata.

Pholadomya (like P. Murchisoni).

Amphidesma? recurva.

Psammobia lævigata (Phil.).

Tellina ampliata (Phil.).

Corbis lævis?

Crassina ovata (Smith).

-_— elegans.

—- aliena (Phil.).

V-- extensa (Phil.).

Venus.

Cytherea.

Corbula curtansata (Phil.).

Cardium lobatum (Phil.).

Isocardia rhomboidalis (Phil.).

Cardita similis.

Trigonia costata. clavellata.

Hippopodium ponderosum.

Nucula.

Cucullæa oblonga.

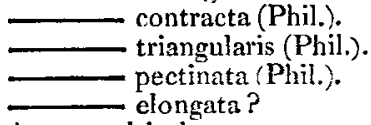

Arca quadrisulcata.

- xmula (Phil.)

Modiola imbricata?

ungulata (Y.\& B.).

Trigonellites antiquatus (Phil.).

Pinna lanceolata.

Perna quadrata.

Gervillia aviculoides.
Avicula expansa (Phil.).

- ovalis (Phil.).

—_ elegantissima (Bean).

$\longrightarrow$ tonsipluma (Y.\& B.).

Plagiostoma læviusculum.

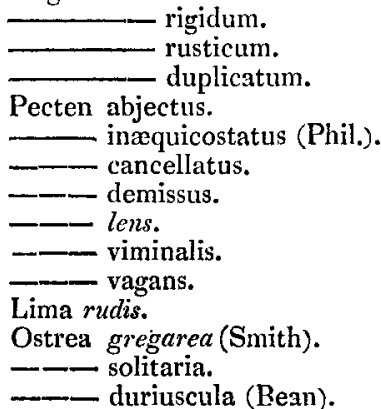

Chama or Gryphæa? mima (Phil.).

Gryphæa bullata?

Terebratula intermedia. globata.

—— ornithocephala.

- ovata?

Orbicula? radiata (Phil.).

Delphinula.

Natica arguta (Smith).

- nodulata (Y. \& B.).

- - cincta (Phil.).

Turbo muricatus.

- - funiculatus (Phil.).

Trochus granulatus.

-_-? tornatilis (Phil.).

Turritella muricata.

- cingenda?

Terebra melanoïdes (Phil.) ? granulata.

Melania Heddingtonensis.

- striata.

Bulla elongata (Phil.).

Murex Haccanensis (Phil.).

Ammonites perarmatus.

- - — - triplicatus.

- - - plicatilis.

_-__- Williamsoni (Phil.).

-__ Lamberti.

-__- Sutherlandiæ.

-__- sublæevis.

___ Ienticularis.

- - vertebralis et cordatus.

Belemnites sulcatus? (Miller). fusiformis? (Miller)

Vermicularia compressa (Y. \& B.).

Serpula squamosa (Bean).

Organic 
Organic Remains in the Coral Rag and Calcareous Grit of

Wood. Midland and Southern England.*

Ichthyosaurus.

Cidaris papillata (Park.).
- intermedia (Park.). diadema (Park.).
Clypeus clunicularis. sinuatus.

Caryophyllia approachingC.carduus. - cespitosa?

Astrea favosiödes (Smith).

Approaching A. annularis.

Ammonites excavatus.

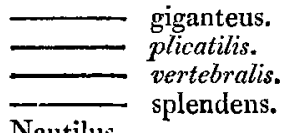

Nautilus.

Belemnites.

Melania Heddingtonensis.

Melania striata.

Turbo muricatus.

Helix?

Trochus bicarinatus.

Ampullaria.

Turritella?

Ostrea gregarea.

- Crista Galli (Smith).

Pecten fibrosils.

lens.

- arcuatus.

Chama.

Trigonia.

Lima mudis.

Lithophaga.

Mytilus.

Modiola.

Serpula.

To these may be added, Pinna lanceolata, Trigonia costata, and T. clavellata, as found at Weymouth. Ostrea deltoidea enters into the upper calcareous grit, and Gryphæa dilatata into the lower calcareous grit of the same place.

Clypeaster.

Cidaris.
Clypeus. Numerous.

Caryophyllia. ?

$\left.\begin{array}{l}\text { Astrea. } \\ \text { Madrepora. }\end{array}\right\}$ Numerons.

Ammonites.

Nantilus.

Melania Heddingtonensis.

Trochus.

Nerinea.

Ostrea gregarea.

- minima.

- a large species.

Lucina or Tellina.

\section{Fossils of the Coral Rag of Normandy. $\dagger$}

Pecten fibrosus?

lens?

similis?

Modiola.

Lima.

Ampullaria.

Venus.

Lucina.

Chama.

Trigonia.

Gervillia.

Mytilus.

Pinna pinnigena.

Dicerata (very abundant).
Polypifers (numerous).

Fossils of the Coral Rag

Crinoidal remains (numerous).

Turrilites, apprs T. Babeli (Brong.).

Melania striata (numerous).

Turritella? ? approaching $M$. lactea.

Terebra apprs T. sulcata (numerous).

Cidarites globaius (Schl.). in the North of France.+.

Echinus.

Echinital spines, (numerous).

Plagiostoma rigidum.

Pecten.

Ostrea gregarea.

Lima rudis.

Terebratula, appr' T. digona.

* Conybeare, Outlines of England and Wales, pp. 187, 188.

+ Desnoyers, Annales des Sciences Naturelles, tom. iv. p. 371 ; and De

Caumont, Topographie Géognostique du Calvados, pp. 128, 129.

+ Boblaye, Annales des Scicnces Naturelles, tom. xvii. p. 72. 
M. Elie de Beaumont notices numerous polypifers and echinital spines in the coral rag and Oxford oolite of Burgundy. The same rocks also contain large Nerineæ, Deciceratæ, large fibrous shells, dentated oysters, striated Terebratulæ, vegetable impressions, \&c.*

M. Dufrénoy describes rocks, which he considers equivalent to coral rag, near Marthon and Rochefoucault, and states that they contain an abundance of polypifers of the same kinds as those of the coral rag, and numerous crinoidal remains. $t$

The reader will perceive that, though the coral rag and Oxford oolite occur in numerous parts of England and France, their organic remains have not been well determined, excepting by Mr. Phillips in Yorkshire. The other published lists are exceedingly defective, more particularly in the catalogue of the polypifers from which the rock has received one of its names. The following list, therefore, of organic remains which have been noticed in more than one of the localities, will be exceedingly meagre; whereas if the polypifers had been better known, it would have been quite the contrary.

\begin{tabular}{|c|c|c|c|c|}
\hline Name. & $\begin{array}{l}\text { York- } \\
\text { shire. }\end{array}$ & $\begin{array}{l}\text { Midl. and } \\
\text { S. Engl. }\end{array}$ & $\begin{array}{l}\text { Nor- } \\
\text { mandy. }\end{array}$ & $\begin{array}{c}\text { North of } \\
\text { France. }\end{array}$ \\
\hline Vegetable remains .......... & 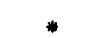 & $*$ & $\cdots$ & $\cdots$ \\
\hline Ichthyosaurus ................ & 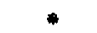 & * & ... & $\ldots$ \\
\hline 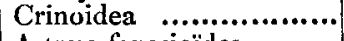 & $*$ & $*$ & $\cdots$ & $*$ \\
\hline Astræa favosioïdes .......... & $*$ & * & $\cdots$ & $\cdots$ \\
\hline Clypeus clunicularis ...... & $*$ & * & $\cdots$ & $\cdots$ \\
\hline 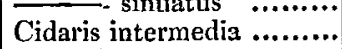 & * & & $\cdots$ & $\cdots$ \\
\hline Trigonia costata ............. & $*$ & - & $\cdots$ & $\cdots$ \\
\hline $\begin{array}{l}\text { Pinna lanceolata } \\
\text { cl............ }\end{array}$ & : & * & 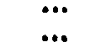 & $\begin{array}{l}\cdots \\
\ldots\end{array}$ \\
\hline Lima rudis................ & $*$ & * & $\ldots$ & $*$ \\
\hline Ostrea gregarea $. . . . \ldots \ldots \ldots .$. & * & * & 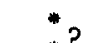 & * \\
\hline Pecten lens $\quad . . . . . . .$. & $*$ & * & $* ?$ & $\cdots$ \\
\hline Melania Heddingtonensis. & $*$ & * & $\ddot{*}$ & $\cdots$ \\
\hline$\overline{\text { Trochus bicarinatus }}$ stria...... & & & $\cdots$ & * \\
\hline 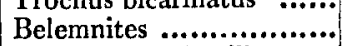 & * & & $\ddot{\cdots}$ & $\cdots$ \\
\hline Ammonites plicatilis ....... & 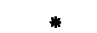 & . & ... & $\ldots$ \\
\hline - vertebr & & & $\cdots$ & $\cdots$ \\
\hline
\end{tabular}

Astræa favosioides is the only polypifer among the numerous species contained in the coral rag, which has been probably determined in more than one locality, unless, indeed, we except the Caryophyllia stated to resemble C. cæspitosa of Ellis and Solander.

* Annales des Sciences Naturclles, Juillet 1829.

+ Annales des Mines, $3^{e}$ liv. 1829, pp. $404 \& 406$.

N.S. Vol. 7. No. 40. April $1830.2 \mathrm{M}$ 


\section{$266 \mathrm{Mr}$. Dela Beche on the GengraphicalDistrilution of Organ}

Of the 13 species of Echinites enumerated in the coralline oolite and calcareous grit of Yorkshire, 6 were first named by Mr. Phillips; of the remainder, 3 are found in Midland and Southern England. The species of Echinites are not enumerated in the Continental lists.

Of the very numerous fossil shells of the Yorkshire lists, the greater proportion are new; 12 of the remainder are found in the other localities; 12 in Midland and Southern England; 3 in Normandy (one being questionable); and 3 in the N. of France.

Of the 21 species contained in Mr. Conybeare's lists, or noticed in the Weymouth beds, 12 are found in the other localities; and of these, 12 are found in Yorkshire, 3 in Normandy ( 1 being questionable*), and 3 in the North of France.

Of the 7 species mentioned in Normandy, 3 are questionable; of the remainder, 3 are found in Northern, Midland, and Southern England, and 1 in the North of France.

Of the 5 species determined with certainty in the coral rag of the North of France, 3 are found in Northern, Midland, and Southern England, and 1 in Normandy.

Ostrea gregarea occurs in all the localities; and Lima rudis, Melania Heddingtonensis, and M. striata, are extensively distributed. It is probable, that when the Echinites and Polypifers shall have been determined with care, many species will be found widely dispersed.

Upper Oolitic System.—Subdivision: Kimmeridge Clay.

We unfortunately at present possess very little information respecting the distribution of the organic remains of either this subdivision or the following. Mr. Phillips gives the following list of the Kimmeridge clay fossils in Yorkshire. $†$

Dicotyledonous Wood.

Ostrea deltoidea.

Belemnites.

Ammonites plicomphalus?

Fragments of Ammonites.

Organic Remains in Midland and Southern England.ł

Plesiesaurus recentior.

Ichthyosaurus.

Belemnites.

Nautilus

Ammonites.

Trochus.

Turbo.

Melania Heddingtonensis.

Ostrea deltoidea.

Pecten.

Avicula.

Astarte lineata.
Astarte ovata.

Trigonia costata.

clavellata.

Venus.

Modiola.

Cardita (Pholadomya).

Cardium.

Mactra.

Tellina.

Chama.

Terebratula.

Serpula.

* Two other questionable species might be added.

+ Geology of Yorkshire, p. 125.

$\ddagger$ Conybeare, Outlines, \&c. pp. 178, 179. 


\section{Fossils of the Kimmeridge Clay (Argile de Honfleur) of Normandy.*}

Crocodilus longirostris.

Plesiosaurus brevirostris.

Ichthyosaurus.

Pholadomya Protei (Alex. Brong.). Amphidesma securiforme (Phil.).

Trigonia costata.

Mya depressa.

Isocardia?

Gervillia siliqua (Deslong.).

Donacites Alduini.

Inoceramus.

Jucina.

Cucullæa.

Terebratula.

\author{
Gryphæa virgula. \\ Ostrea deltoidea. \\ -.. Crista Galli. \\ - gregarea.
}

Pteroceras Oceani (Alex. Brong.). Ponti (Alex. Brong.). Pelagi (Alex. Brong.).

Melania Heddingtonensis. striata.

Rostellaria composita.

Trochus.

Belemnites.

Teredo.

Serpula.

Cidaris.

Lignite.

Of the organic remains contained in the Kimmeridge clay of other parts of France little is known, except that the Gryphæa virgula is very abundant, and as characteristic of this clay in that country as the Ostrea deltoidea is in England.

M. Dufrénoy, describing some marls near Angoulême, gives a list of the following fossils, but seems to refer them to the upper part of the middle oolitic system, though they pass (descent to the Pont de la Trouve) into marls full of the Gryphæa virgula. $\dagger$

Mya mandibulata.

- depressa.

Pholadomya ovalis.

Pholadomya acuticosta.

Trigonia clavellata.

Natica sinuosa?

Besides the Gryphæa virgula contained abundantly in the Kimmeridge clay of the environs of Cahors (South of France), M. Dufrénoy mentions Terebratula perovalis. Lignite occurs in this clay or marl near the Pont de Rodes.

From the above the following small Table may be formed:

\begin{tabular}{|c|c|c|c|c|}
\hline Name. & $\begin{array}{c}\text { York- } \\
\text { shire. }\end{array}$ & $\begin{array}{c}\text { Midl. and } \\
\text { S. Engl. }\end{array}$ & $\begin{array}{c}\text { Nor- } \\
\text { mandy. }\end{array}$ & $\begin{array}{c}\text { Angoul- } \\
\text { lême. }\end{array}$ \\
\hline Plesiosaurus recentior ... & $\ldots$ & $*$ & $*$ & $\ldots$ \\
Ostrea deltoidea ........ & $*$ & $*$ & $*$ & $\ldots$ \\
\hline Gryphæa virgula ......... & $\ldots$ & $*$ & $*$ & $\ldots$ \\
Trigonia clavellata......... & $\ldots$ & $\ldots$ & $*$ & $*$ \\
\hline Mya depressa.................. & $\ldots$ & $*$ & $\ldots$ & $*$ \\
\hline
\end{tabular}

* Alex. Brongniart, Tableau des Terrains, \&c.pp. 410,411 ; De Caumont, Topographie Géognostique du Calvados, pp. 117, 118; and Phillips, Phil. Mag. and Annals, March 1830.

† Annales des Mines, deuxième série, tom. v. p. 414 . 


\section{Dr. Bostock on the Purification of Thames Water.}

Subdivision: Portland Stone.

Although this rock, as has been before stated, is observed in points crowning the oolitic series in England and France, its organic remains have not been well described except in Midland and Southern England: I shall therefore content myself by referring to Mr. Conybeare's lists.*

[To be continued.]

XXXVII. On the spontaneous Purification of Thames Water. By Joh n Bostock, M.D. F.R.S. \&c. †

TN the Report respecting the analysis of the water of the Thames, which I presented, in April 1828, to the Commissioners appointed by His Majesty to inquire into the supply of water in the metropolis, $I$ have stated that when the experiments were nearly brought to a close, a quantity of water was sent to me, purporting to have been "taken in the river, in the current of, and immediately at the mouth of the King's Scholars' Pond sewer." I described it as " in a state of extreme impurity, opaque with filth, and exhaling a highly foetid odour." When it had been about a week in my possession, a considerable quantity of black water subsided from it, but the fluid was still dark-coloured and opaque, and nearly as offensive as at first, while the odour and colour were only in part removed by being passed through a layer of sand and charcoal six inches in thickness.

The water remained for some time in my laboratory without being atlended to; when, after an interval of some weeks, I observed that a great change had taken place in its appearance. It was become much clearer, whilst nearly the whole of the sediment had risen to the surface, where it formed a pretty regular stratum of about half an inch in thickness; the odour, however, still continued extremely offensive, perhaps even more so than at first. From this time the process of depuration, which had thus spontaneously commenced, was continued for about eight weeks, when the water became perfectly transparent, without any unpleasant odour, although still retaining somewhat of its original dingy colour.

After the formation of the scum mentioned above, the next change that I observed was its separation into large masses or flakes ; to these, as well as to the scum itself, a number of minute air bubbles were attached, to which, no doubt, they owed their buoyancy : after some time the masses again subsided, leaving the fluid almost totally free from any visible extraneous matter. The quantity of gas discharged was inconsiderable,

* Outlines of the Geology of England and Wales, p. 176.

+From the Philosophical Transactions for 1829 , part ii. 